Article

\title{
Emerging Adult Religiosity and Spirituality: Linking Beliefs, Values, and Ethical Decision-Making
}

\author{
Patricia Snell Herzog ${ }^{1, *(1)}$ and De Andre' T. Beadle ${ }^{2}$ \\ 1 Department of Sociology \& Criminology and Center for Social Research, University of Arkansas, \\ 218 Old Main Building, Fayetteville, AR 72701, USA \\ 2 Department of Sociology, University of Minnesota, Minneapolis, MN 55455, USA; bead1030@umn.edu \\ * Correspondence: herzog@uark.edu
}

Received: 23 February 2018; Accepted: 12 March 2018; Published: 16 March 2018

\begin{abstract}
This paper challenges the "spiritual but not religious" (SBNR) category as a methodological artifact caused by interacting two closed-ended survey items into binary combinations. Employing a theoretically rich approach, this study maps the multiple ways in which the religious and the spiritual combine for emerging adults. Results indicate that most emerging adults have a tacit sense of morality, displaying limited cognitive access to how moral reasoning relates to religious and spiritual orientations. This longitudinal study investigates efforts to raise moral awareness through: exposure to diverse religious and spiritual orientations, personal reflection, and collective discussion. Relative to control groups, emerging adults in this study display increases in moral awareness. We combine the results of these studies to formulate a theoretical framework for the ways in which beliefs, values, and ethical decision-making connect in expressing plural combinations of religiosity and spirituality. The implication is that direct attention to religiosity and spirituality — not avoidance of - appears to facilitate ethical decision-making.
\end{abstract}

Keywords: adolescents; youth; culture; morality; ethics; theory

\section{Introduction}

This study investigates the nuances of the term "spiritual but not religious," commonly known as SBNR. Rather than treating the interaction between religiosity and spirituality as binary, we investigate the multi-dimensional ways in which spirituality and religiosity combine for American emerging adults. Moreover, we study whether and how religious and spiritual beliefs link to cultural values and ethical decision-making. To do so, we combine analyses from two related studies - the first is a nationally representative survey, and the second is a longitudinal experiment.

The first set of data analyzed is from the National Study of Youth and Religion $(n=2144)$ and focuses in particular on the fourth wave of in-person interviews conducted in $2013(n=300)$. Our qualitative analysis centers on responses to questions regarding religiosity, spirituality, morality, and ethical decision-making. We reveal a complex array of overlapping combinations of religiosity and spirituality, which poses challenges for the utility of SBNR as a discrete and homogeneous category. Findings also indicate that most emerging adults have a tacit sense of morality, with limited cognitive access to their reasoning for deciding moral actions as they relate or not to their religiosity and spirituality.

The second set of data analyzed is from an in-depth study conducted with a business school course $(n=109)$. The intervention objective is to develop greater moral awareness to improve ethical decision-making. In this study, we investigate whether emerging adults gain greater cognitive access to their moral action reasoning through exposure to diverse religious and spiritual value orientations, combined with personal reflection and collective discussion. We also study whether and how changes 
in moral awareness relate to ethical decision-making. Quantitative and qualitative analyses of the treatment and control group results are compared to national benchmarks. The treatment group is compared to control groups of students who are in the same business school and enrolled in traditional ethics courses, which do not focus on developing moral awareness of the cultural, religious, and spiritual underpinnings to ethical decision-making. Findings that participants in the treatment gain an increased capacity to articulate moral values and evidence decreasing levels of instrumental, self-benefit rationale, as compared to their peers in the ethics-only control groups.

We combine the results of these studies to formulate a theoretical framework for the ways in which beliefs, values, and ethical decision-making connect in expressing diverse combinations of religiosity and spirituality. The national findings reveal complexities in the pluralistic expressions of multiple forms of religiosity and spirituality in American young people. The in-depth study of results from concerted efforts to clarify links between beliefs, values, and ethical decision-making indicate gains in moral awareness. We find these efforts are facilitated-not hindered-by exposure to diverse religious and spiritual orientations. One implication of this study is that efforts designed to promote ethical decision-making are aided by direct attention to religiosity and spirituality, and their pluralistic combinations.

\section{Literature Review}

\subsection{Spiritual But Not Religious}

In an implicit secularization narrative, initial interest in the relationship between religion and spirituality was typically focused on narratives of decline in the former, institutional versions of faith and a rise in the latter, individualized forms of faith (Zinnbauer et al. 1999). However, contemporary sociologists of religion instead identify that a combination of the two categories exists and appears to be rising over time (Chaves 2011). Studies investigating this combination contributed to a popularization of a new cultural category of "spiritual but not religious" (Oppenheimer 2014). The abbreviation of this term — "SBNR" - is common lexicon in many circles, even in popular website addresses (SBNR n.d.).

Ammerman (2013) presents a taxonomy of the cultural packages that represent religiosity and spirituality, and especially their various combinations. Describing the lexicon of religious and spiritual labels, Ammerman describes the moral boundary work involved in the cultural usage of the term "spiritual but not religious." She distinguishes between how this label has been interpreted in extant scholarship on religion, on the one hand, from how typical Americans describe their combinations of these categories, on the other hand. The inductive qualitative analysis revealed four "cultural packages"-Theistic, Extra-Theistic, Ethical Spirituality, Belief and Belonging Spirituality. This qualitative analysis challenges the SBNR category as a methodological artifact caused by interacting two closed-ended survey items into binary combinations. However, the study has notable limitations to generalizability, as the findings are based on a quota sample of 95 study participants selected to represent the general distribution of Christian and Jewish traditions in the Boston and Atlanta areas, both of which are eastern and urban locales.

The current study improves the generalizability of this line of inquiry by investigating the potential for non-binary combinations of religiosity and spirituality in a nationally representative study with participants located in all U.S. Census regions and in a mixture of urban, suburban, and rural locales. Moreover, this study additionally contributes an in-depth focus on religiosity and spirituality in particular among emerging adults, who are reportedly increasing in SBNR relative to prior generations (Wuthnow 2007). This provides insight into the future of American religion, and the ways in which religiosity and spirituality combine for forthcoming generations. We also extend the understanding of religiosity and spirituality among emerging adults by analyzing how cultural packages relate to moral reasoning. In linking beliefs, values, and ethical decision-making, we analyze whether emerging adults are cognitively aware of the beliefs that undergird their moral actions, or whether their beliefs are tacitly held beneath cognitive awareness. 


\subsection{Moral Awareness and Ethical Decision-Making}

Moral development has long been found to be a key task during young adulthood (Erikson 1950; Kohlberg 1964; Padilla-Walker 2016). Moreover, clarity on moral values is generally considered to be key in undergirding ethical decision-making (Gentile 2010; Comer and Vega 2011; Giacalone 2007). Yet value orientations differ across religious and spiritual beliefs (Jensen 2008; Guerra and Giner-Sorolla 2010), and growing diversity in the American religious landscape (Putnam et al. 2012) coupled with rising globalization calls for greater interdisciplinary investigations into how ethical practices are shaped by diverse beliefs and values (Kenworthy 2013). The current study contributes to greater understanding of how religious and spiritual beliefs are linked to moral values and expressed in ethical decision-making. We first identify the combinations of religious and spiritual beliefs in the general population of young Americans, and we then investigate how these cultural packages are linked to ethicality with in-depth study. Specifically, we contribute an experimental intervention designed to increase greater moral awareness and ethical decision-making.

\section{Methodology}

This paper draws upon two studies-a nationally representative survey of young Americans and a longitudinal experiment assessing an intervention in moral awareness.

\subsection{National Survey}

\subsubsection{Data}

The first data set utilized in this study is from the National Study of Youth and Religion (NSYR). The NSYR is a mixed-methods study that collected nationally representative and longitudinal survey data on randomly sampled respondents, as well as in-depth interviews with a subset of the survey respondents (Smith and Snell 2009; Smith and Denton 2005). The respondents began the study in 2001 as adolescents ages 13 to 17 years old ( $81 \%$ response rate), and the same panel of respondents was resurveyed in a total of four waves of data collection, concluding with Wave 4 in 2013 when respondents were ages 23 to 27 ( $n=2144,65 \%$ retention rate from Wave 1). Diagnostic analyses comparing NSYR data with U.S. Census data on comparable households and with other nationally representative adolescent surveys - such as Monitoring the Future, the National Household Education Survey, and the National Longitudinal Study of Adolescent Health-confirm that the NSYR provides a nationally representative sample without any major identifiable sampling and nonresponse biases of U.S. teenagers ages 13 to 17 and their parents living in households. In addition, statistical weights adjust to population rates.

In-depth interviews were conducted with a stratified quota sample of survey respondents in each of the four waves. The fourth wave of data collection entailed in-depth interviews with 300 respondents (68\% interviewed in Wave 1, 18\% sampled for interviews in Wave 3 and re-interviewed in Wave 4, and $14 \%$ newly sampled in Wave 4 ). The interviews averaged four hours in length with most interviews being conducted on-site in coffee shops, libraries, and restaurants, near the interviewee's residence. All interviews were recorded and transcribed, and additionally, each interviewer wrote field notes on the interview location and on the interviewee. This study focuses in particular on interview data from Wave 4, collected during the summer of 2013.

\subsubsection{Measures}

This analysis focuses in particular on the section of open-ended interview questions asking about religion, spirituality, and moral values. The primary questions analyzed were: "How would you describe yourself to me in terms or your religion or spirituality?" and "With which religious group do you identify most strongly?" Depending upon how interviewees answered these questions, they were asked different follow-up questions specific to their religious affiliations. Also analyzed were responses to: "Do you consider yourself to be spiritual but not religious?" In addition, we analyzed responses to 
a set of questions about morality. We paid particular attention to responses to a question that asked: "How do you normally decide or know what is good and bad, right and wrong in life?" Follow-up questions to this included: "In general, is it easy or hard for you to decide between right and wrong?" "What do you think it is that makes something right or wrong? "Responses to these questions form the basis of the second section of results on ethical morality. To analyze the qualitative interviews, we employed the software program called NVivo, from QSR International@. Initially, this resulted in eleven subcategories grouped into four meta-categories. As described in the results section, we later added two additional subcategories based on emergent themes in the analysis.

\subsubsection{Analysis}

We employed a deductive content analysis technique. In developing our coding scheme, we combine the cultural packages developed by Ammerman (2013) with other findings in the sociology of religion of young Americans. First, Wuthnow (2007) finds many young Americans to be "tinkerers," taking a theistic approach but combining multiple doctrines. We thus distinguish this from doctrine-specific theism through two subcategories: Doctrine-Theistic and Hybrid-Theistic. Second, Smith and Denton (2005) find that the beliefs of many young Americans are what they term "moralistic therapeutic deism," a theistic belief focusing on personal therapy that does not directly derive from and comport with most doctrine-based theisms. We identify this as a third subcategory: Therapeutic-Theistic. Third, Smith and Snell (2009) find that a sizable proportion of emerging adults are "religiously indifferent," raised in religious families and now not actively accepting nor actively rejecting religiosity, nor describing themselves as spiritual. We label this group as a fourth subcategory: Heritage-Theistic, referring to their professing theistic beliefs more as a way of identifying with their family heritage than active religiosity.

Moreover, we code for the three subcategories of Extra-Theism-self, community, and natural (Ammerman 2013, p. 268). In Durkheimian fashion (Durkheim 2008), Ammerman describes this cultural package to be one based on transcendence through experiences of being part of something bigger than oneself. This form of spirituality is not antithetical to religion, as it comports well with certain religious traditions. For example, "New Age" religions tend to focus on transcendence to the supernatural realm through self-enlightenment (Farias and Lalljee 2008). Alternatively, transcendence through community belonging and congregational affinity is part of the theology in many Protestant denominations (Roof and McKinney 1992; Marti 2009). Transcendence through connection to the natural world is the basis of other forms of religion (Crosby 2003). However, some studies find that New Age religions tend to involve spirituality through a combination of all three- self, others, and nature (Berghuihs et al. 2013). Thus, we investigate the Extra-Theistic cultural package in three subcategories-Self-Extra-Theistic, Community-Extra-Theistic, and Natural-Extra-Theistic, and their overlap.

The third cultural package described by Ammerman is Ethical Spirituality, which is similar to the kind of "Golden Rule Christianity" in Ammerman (1997). This is a group for whom religious participation is not necessarily important and who do not focus on doctrine or theism in describing their religious beliefs. They find spirituality instead in everyday acts of kindness, in living a virtuous life through a belief that it is important to act ethically but without necessarily having any specific connection to religious tenets. We combine this with studies finding standards of ethicality that do not appear to be based upon a sense of spirituality, for example among scientists (Baker 2012). We thus investigate Ethical Morality, as based on transcendental beliefs or not and investigate whether this category is distinct from or overlapping the other cultural packages.

The fourth cultural package that Ammerman identifies is Belief and Belonging Spirituality. This is the category containing the contested "spiritual but not religious" group that is meant in the binary distinction against which Ammerman argues. The term refers to a concept articulated by Davie (1994), which is that the importance of faith in religious beliefs remains high in modern industrialized nations such as England but that there has been a decline in belonging to religious denominations. The term 
has generally come to refer to people who believe in religious tenets but do not participate in public, social forms of religiosity such as religious attendance or membership to religious congregations or denominations. However, Ammerman uses it to refer to a more antithetical position, which is people who reject organized religion as something not desirable and see believing as something less authentic when coupled with belonging. Interviewees in this group refer to people who view believing and belonging as "going through the motions," and see this as an absence of meaningful spirituality. In this sense, we view this category to be more clearly labeled as "Believing But Not Belonging."

Finally, we note the absence of atheists and agnostics within the cultural package categorization and consider whether they fit within this fourth cultural package if we view atheists and agnostics as believing and belonging to a secular humanistic identity (Cimino and Smith 2007). We take this approach based upon findings that some atheists participate in collective identity formation in community and activist groups that mirror religious participation but with non-theistic belief systems (LeDrew 2013; Smith 2013). We thus investigate whether Ammerman's Believing and Belonging category, applied to a national study of emerging adults, may contain two subcategories: Non-Religious Agnosticism and Non-Theistic Atheism, both of which could entail belonging with similar secular peers.

\subsection{Longitudinal Experiment}

\subsubsection{Data}

The second set of data is drawn from a longitudinal experiment designed to raise moral awareness among emerging adults. Data were collected through three formats-surveys, personal mission statements, and participant essays. We collected survey data in January 2015 (Time 1) and again in May 2015 (Time 2). Survey data were collected through a survey administered via Qualtrics (an enterprise research platform) that was completed with 97 percent response rate $(n=109)$. The sample consists of college-enrolled undergraduate students in a southern business school. The treatment group consists of students enrolled in a class designed to promote ethical decision-making through developing greater moral awareness. The intervention entails: (1) exposure to diverse religious and spiritual belief orientations; (2) personal reflection on cultural values and moral awareness of beliefs undergirding ethical decision-making; and (3) collective discussion of diverse views. Changes over time in this group are compared to two control groups of similar students enrolled in a class designed to promote ethical decision-making through traditional ethics courses, which do not intentionally focus on developing moral awareness or facilitate direct attention to cultural values and beliefs regarding religion and spirituality.

In addition to the quantitative survey measures assessing changes over time between the treatment and control groups, additional qualitative data were collected with intervention group participants. These include a personal mission statement in which participants articulated their moral values and how they plan to enact these values in their life and workplace ethical decision-making. Also collected were essays from treatment group participants, with written reflections on whether they experienced any changes from participating in the intervention and if so what aspects of the intervention contributed to those changes.

\subsubsection{Measures}

The survey measures provide comparisons between the regional sample and national averages, as well as analysis of changes over time in survey responses between the treatment and control groups. Key morality questions included: If you were unsure what was right or wrong in a particular situation, how would you decide what to do; would you most likely: do what would make you feel happy, do what would help you to get ahead, follow the advice of a parent or teacher or other adult you respect, or do what you think God or the scripture tells you is right? and agree-disagree with: "Regardless of concerns about principles, in today's world you have to be practical, adapt to opportunities, and do 
what is most advantageous for you." In addition, participants were asked to agree-disagree with the following statements: "I have a clear understanding of my faith (core beliefs) and values;" "I am confident that I could articulate my beliefs and values accurately and respectfully in the workplace." Participants were also asked whether they can identify their top five values: easily, with some thought, after quite a bit of thought, with difficulty, or not at all.

\subsubsection{Analysis}

The mixed-methods approach to this study involves both the quantitative analysis of deductively designed survey measures and qualitative analysis of inductively-coded data collected through participant personal mission statements and intervention reflection essays. Small sample t-tests are employed to assess statistically significant differences between the regional sample and national averages, as well as to assess differences in changes over time between treatment and control group participants. To analyze the qualitative mission statement and essay data, we employed a software program called NVivo, from QSR International $\odot$. We inductively coded the primary themes in both sets of data and report these in the longitudinal experiment results.

\section{Results}

\subsection{Survey Results}

Table 1 summarizes the primary results from the national study. Overall, we found support for the existence of ten cultural package subcategories. There was also evidence of overlap among some of the categories. In particular, Ethical Morality was a crosscutting category that was not a fourth cultural package and rather a more behavior-oriented set of themes than the belief-oriented set of themes described in the three cultural packages. We thus group these below into a section of results on belief-based cultural packages and a second section of results on ethical morality.

\subsubsection{Theistic Cultural Packages}

Doctrine-Theistic. Many emerging adults described their religious beliefs in ways that were doctrinally specific and theistic. For example, when asked "What would it take for you to stop believing, if anything?" one emerging adult said, "This answer won't make sense, but it'd take Jesus to come and tell me that the Bible is wrong." Another described reading the Bible and said he did this because, "the Lord wants to be in a relationship with us, and my being in a relationship with God is the way that I talk to Him through prayer, but the way I hear from him, most times, is through his word, I think." He goes on to say: "So, I read it to be in a relationship with Him; I read it to hear from Him; I read it to be comforted; I read it to know what's right."

While these two examples came from Christian emerging adults, there are also many emerging adults who are not Christian in the Doctrine-Theistic group. For example, a Hindu emerging adult stated, "We're Hindus. Spiritually there's an organization called Swadhayaya, which means self-study. So, spiritually we follow that." She continues by describing her faith's tenets in this way: "We really just focus on ourselves, and the scripture that we focus on is the Gita, which all Hindus know about." Likewise, a Jewish emerging adult stated: "The Torah is the foundation of Jewish belief, and we believe that God gave it to Moses at Mount Sanai and that it came right from him or the being, general neutral being." He continues by stating, "That's kind of a foundation and then [there is] the Talmud which is tens of thousands of laws." Describing himself as a reformed Jew, he explains: "Reformed Jews aren't really [supposed to] have a lot of Talmudic influence in their life, but I think that came from God too. So while I'm not as studied in it, I do believe in it and its importance." Of the 300 interviews in the sample, 69 of them were emerging adults we categorized to be Doctrine-Theistic. 
Table 1. Taxonomy of Belief-Based Cultural Packages and Moral Values in Ethical Decision-Making.

\begin{tabular}{|c|c|c|c|c|c|c|c|}
\hline Belief-Based Cultural Packages & $\begin{array}{l}\text { Only } \\
\% / n\end{array}$ & $\begin{array}{l}\operatorname{Mix} \\
\% / n\end{array}$ & $\begin{array}{l}\text { Total } \\
\% / n\end{array}$ & $\begin{array}{c}\text { Moral Values in } \\
\text { Ethical Decision-Making }\end{array}$ & $\begin{array}{l}\text { Only } \\
\% / n\end{array}$ & $\begin{array}{l}\text { Mix } \\
\% / n\end{array}$ & $\begin{array}{l}\text { Total } \\
\% / n\end{array}$ \\
\hline Theist & $\begin{array}{l}62.67 \\
(188) \\
\end{array}$ & $\begin{array}{l}4.00 \\
(12)\end{array}$ & $\begin{array}{l}66.67 \\
(200) \\
\end{array}$ & (A) Tacit Morality & $\begin{array}{l}71.67 \\
(215) \\
\end{array}$ & 8 & 223 \\
\hline (1) Doctrine-Theist & $\begin{array}{l}23.00 \\
(69)\end{array}$ & $\begin{array}{c}0.33 \\
(1)\end{array}$ & $\begin{array}{c}23.33 \\
(70)\end{array}$ & (A1) Tacit-Religious & $\begin{array}{l}32.67 \\
(98)\end{array}$ & 4 & 102 \\
\hline (2) Hybrid-Theist & $\begin{array}{c}1.00 \\
(3)\end{array}$ & $\begin{array}{c}1.67 \\
(5)\end{array}$ & $\begin{array}{c}2.67 \\
(8)\end{array}$ & (A2) Tacit-Non-Religious & $\begin{array}{l}39.00 \\
(117)\end{array}$ & 4 & 121 \\
\hline (3) Therapeutic-Theist & $\begin{array}{l}17.67 \\
(53)\end{array}$ & $\begin{array}{c}0.33 \\
(1)\end{array}$ & $\begin{array}{c}18.00 \\
(54)\end{array}$ & & & & \\
\hline (4) Heritage-Theist & $\begin{array}{l}21.00 \\
(63)\end{array}$ & $\begin{array}{l}1.67 \\
(5)\end{array}$ & $\begin{array}{c}22.67 \\
(68)\end{array}$ & & & & \\
\hline Extra-Theist & $\begin{array}{c}0.33 \\
(1)\end{array}$ & $\begin{array}{c}11.33 \\
(34)\end{array}$ & $\begin{array}{c}11.67 \\
(35)\end{array}$ & (B) Cognitive Morality & $\begin{array}{l}24.33 \\
(73)\end{array}$ & $\begin{array}{l}3.00 \\
(9)\end{array}$ & $\begin{array}{c}27.33 \\
(82)\end{array}$ \\
\hline (5) Nature-Extra-Theist & $\begin{array}{c}0.00 \\
(0)\end{array}$ & $\begin{array}{l}4.67 \\
(14)\end{array}$ & $\begin{array}{l}4.67 \\
(14)\end{array}$ & (B1) Cognitive-Religious & $\begin{array}{c}2.33 \\
(7)\end{array}$ & $\begin{array}{c}0.33 \\
(1)\end{array}$ & $\begin{array}{c}2.67 \\
(8)\end{array}$ \\
\hline (6) Self-Extra-Theist & $\begin{array}{c}0.33 \\
(1)\end{array}$ & $\begin{array}{c}3.00 \\
(9)\end{array}$ & $\begin{array}{l}3.33 \\
(10)\end{array}$ & (B2) Cognitive-Non-Religious & $\begin{array}{l}22.00 \\
(66)\end{array}$ & $\begin{array}{l}2.67 \\
(8)\end{array}$ & $\begin{array}{c}24.67 \\
(74)\end{array}$ \\
\hline (7) Community-Extra-Theist & $\begin{array}{c}0.00 \\
(0)\end{array}$ & $\begin{array}{l}3.67 \\
(11)\end{array}$ & $\begin{array}{l}3.67 \\
(11)\end{array}$ & & & & \\
\hline (Not) Belief, (Not) Belonging & $\begin{array}{c}26.33 \\
(79)\end{array}$ & $\begin{array}{l}6.33 \\
(19) \\
\end{array}$ & $\begin{array}{c}32.67 \\
(98)\end{array}$ & & & & \\
\hline (8) Non-Religious & $\begin{array}{l}10.33 \\
(31)\end{array}$ & $\begin{array}{l}2.00 \\
(6)\end{array}$ & $\begin{array}{c}12.33 \\
(37)\end{array}$ & & & & \\
\hline (9) Non-Religious-Agnostic & $\begin{array}{l}10.00 \\
(30)\end{array}$ & $\begin{array}{l}3.33 \\
(10)\end{array}$ & $\begin{array}{c}13.33 \\
(40)\end{array}$ & & & & \\
\hline (10) Non-Religious-Atheist & $\begin{array}{l}6.00 \\
(18)\end{array}$ & $\begin{array}{l}1.00 \\
(3)\end{array}$ & $\begin{array}{l}7.00 \\
(21)\end{array}$ & & & & \\
\hline Combined Total & 268 & 65 & $300 *$ & Combined Total & 288 & 17 & $300 *$ \\
\hline
\end{tabular}

Note: Only refers to the number of respondents who communicated only that one cultural package. Mix refers to respondents who communicated that cultural package in combination with another package. * Interviews total to $300 ; 33$ entirely overlap cultural packages and 5 entirely overlap moral values. 
Hybrid-Theistic. Also under the broader Theistic cultural package was a subgroup of "tinkerers," who combine doctrine from different faith traditions. For example, when asked what she believed, one emerging adult said, "Like, the deities and, like, the Hinduism and Buddhism and things like that, and I kinda just, like, pick and choose, like, what I like out of everything, so." She described where these combined beliefs came from by saying, "Just learning about a lot of the beliefs that people in yoga tend to have." Another emerging adult asked to describe his religion said, "Islam and Hinduism, I think." The interviewer asked, "Both of those?" To which he replied, "Yes, the combining of the two." A third emerging adult summed this category well when she stated, "Maybe I'm like omni-religious." While we found evidence for the existence of this category, there were only three emerging adults who expressed their religious beliefs in a way that could be described as Hybrid-Theistic and without overlapping into another category.

Therapeutic-Theistic. Another large group comprised of individuals who employed religion for its emotional and spiritual benefits, but differed from the Doctrine-Theistic group due to their lack of emphasis on established doctrine, traditions and involvement. Many of the emerging adults in this group were secure in their beliefs, but not necessarily concerned about making religion a core aspect of their identity with one participant identifying that she only prays as a "last resort kind of thing." One interviewee described his relationship with God as "a distant friend I guess. Someone I look up to and know is around, um, but don't always feel accountable to." Especially common in this group was a reliance on God for support during troubling times with one young woman, who described herself as a "pretty bad Catholic," saying that she uses religion primarily as a means to "cope with certain things in my own head, and that's what gets me through." Akin to Smith and Denton (2005), we view this group as a Therapeutic-Theistic package that has religiosity in its belief contents but which is not based on any particular religious doctrines. Overall, 53 of the 300 emerging adults were categorized into this group.

Heritage-Theistic Package. This final group is comprised of respondents who identified as religious, but who actively exhibit little religious practices or beliefs. This group primarily consists of people who were born and raised within their faith tradition, such as one participant stating that she was a Christian because that was "how I grew up, so that's what I believe." However, a disconnect between belief and practice exists within this group. When one emerging adult was asked what his religious affiliation was, he responded with a noncommittal reference to his upbringing: "like growing up had a strong Catholic um, Christian tradition." He identified that he was religiously inactive, but said that Christianity was still "part of my heritage."

Many aspects of religion are still salient with emerging adults in this group, but without any description of religious content as presently meaningful to them, other than through a heritage connection with family and traditions. For example, one interviewee explained that on Christmas "we have presents and stuff. We don't go to church or nothin' though." Many Jewish emerging adults, describing themselves as culturally Jewish, occupied this group. One Jewish man stated both that he observed "like the blood heritage of the Jews," but also said: "I'm not religious at all." The themes of family ties and intergenerational commitment permeated this group. Of the 300 interviews, 63 were identified as Heritage-Theistic.

Combined, a total of 188 of the 300 interviewees were categorized in the Theistic cultural package. In addition, another 12 interviewees expressed some aspects of Theism but also described the contents of one of the other cultural packages. Of these partial-theistic interviewees, one was part-doctrinal, five part-hybrid, one part-cultural, and five part-heritage. If counted within the Theistic Package, this equates to two-thirds of these emerging adults.

\subsubsection{Extra-Theistic Cultural Packages}

Self-Extra-Theistic. Among emerging adults who emphasized spirituality, some emerging adults experienced religion and spirituality as being rooted, in part, by inward reflection and self-actualization. For example, A Buddhist emerging adult expressed the belief that each person has the opportunity to 
achieve "Buddha nature or their highest potential." She elaborated further by stating that she believes that all religions are rooted in the same core belief: "that each one of us has this higher potential, and we try to bring that out." Furthermore, another interviewee conveyed that he believed that "some people's personalities are just too, too big to just cease being," though he added: "I don't know what that means though." Common themes in this group consist of schools of thought outside of Western Religion, like Buddhism, and meditation and mindfulness, some of which overlapped with Doctrine-Theistic and Heritage-Theistic packages. Similar to Nature-Extra-Theistic, we did not classify any interviewee solely as Self-Extra-Theistic, rather 11 were partially in this group.

Community-Extra-Theistic. Other emerging adults experienced religion through their social relationships with other people. One young man expressed his belief that "God is within, God is among us" and that spirituality is represented by "extending our love through our experience." Auras and spiritual, energy connections between individuals are another common theme in this group. One interviewee described her energy as being like a "bubble" that has the ability to affect other people, and inversely other people's energy can affect her back. She described: "I'm sitting here, and my body doesn't really end here." Similarly, another emerging adult emphasized the uniqueness of each individual's energy stating that: "when you add one person to a group of like five people, that one person is gonna change the dynamic of the whole group and that's because of the energy they bring in." Overall emerging adults in this group described feeling a spiritual, but yet almost tangible link between themselves and others. This link affected the way they organized their spirituality. In terms of how many interviewees were in this category, it shared a commonality with the other Extra-Theistic packages in having more overlap than non-overlap, with nine emerging adults partially expressing Community-Extra-Theism. Unlike the other extra-theistic cultural packages, there was one individual who we exclusively categorized as Community-Extra-Theistic. Together, there was only one emerging adult who was solely Extra-Theistic, though there were an additional 34 interviewees who expressed one of the three types of extra-theism partially, in combination with the Theistic or the Non-Religious packages.

Nature-Extra-Theistic. Connectedness to nature was frequently referenced among emerging adults who emphasized spirituality. One Christian emerging adult described God as being a part of everything by saying: "I feel like God is in you, and God is in me. I feel like God is in the air. God is in the electricity." In other interviews, Nature-Extra-Theism was used to join science and religion together. One participant described spirituality as "kind of like um, in physics you have entropy. And so that's just like the natural degradation of everything around you. And so for me, my spirituality, it helps me to fight against that entropy basically." In addition, emerging adults in this category saw religion and spirituality reflected in, as one emerging adult put it, "both the beauty and power, as well as the sorrow and irrationality of nature." While no participant was categorized as exclusively Nature-Extra-Theistic, 14 emerging adults were partially Nature-Extra-Theistic, while also expressing content that overlapped another of the cultural packages.

\subsubsection{Non-Religious Cultural Packages}

Non-Religious. In contrast to the two prior groups, some emerging adults explicitly described themselves as being without a religious affiliation of any kind. These Non-Religious emerging adults can be further separated into three groups. Some of the Non-Religious emerging adults constructed their identity in a more passive way. One interviewee stated "I definitely don't acknowledge myself [as] bein' religious." However, he continues by describing that his religious values were so ingrained into him that "I can't shake them." Contrary to Heritage-Theistic individuals, many of these emerging adults de-emphasized religion or spirituality and did not have a strong identification with the religion of their heritage. For example, one young woman said, "I wish I went to church more, but more because I kinda miss that community of church." She then said: "other than that I'm not a spiritual person; I'm not a religious person." Conversely, other Non-Religious emerging adults constructed their identity in a more active and reactionary manner. These individuals expressly rejected the labels of 
Agnostic and Atheist, and created their own labels for themselves. One emerging adult recognized the importance that religion played in many people's lives. However, he viewed religion "as judgmental and not open to change or any kind of sort of personal thought process." He said he considered religion to be "just one of those things that I find it's not for me." Another individual who identified himself as Non-Religious said, "I would say that I believe in a higher being, like God, but I think that that is a really broad and big concept." Furthermore, he rejected other theistic or nontheistic labels due to his belief that religion is "a personal experience; it's a personal idea." In this way, he shared some overlap with the Self-Extra-Theistic package. Overall, we categorized 31 of these emerging adults as Non-Religious, with an additional six who we categorized as partially Non-Religious.

Non-Religious-Agonistic. In addition, other emerging adults more explicitly identified as agnostic or were characterized by their not knowing the truth of any religion. As one emerging adult explained, "people think that an agnostic is someone who just sits on the fence and doesn't care either way." However, he stated that he does care and identified as "an agnostic theist," which he described as someone who states: "that you don't know." He further added: "everybody's agnostic. They just don't want to admit it." Other young people express agnosticism as a way to rectify science and religion together. These emerging adults believe there is no way to scientifically identify whether God is real. However, as one emerging adult describes: “If God is omnipotent, then why couldn't have God created photosynthesis? Why couldn't he have God created evolution?" Thus, some in this category are partially Theistic in their cultural package, but with the distinct difference that they explicitly state not knowing if they believe theistically. Another common theme in this category was references to events in religious upbringings that pushed youth away from theistic beliefs. For example, one young woman expressed the discomfort she felt when her youth pastor told her "God punished [R\&B singer] Aaliyah, and that's why she died." She expressed: "with me religion kinda comes with judgment," and she attributes that experience as having prevented her from being fully Theistic. In total, there were 30 emerging adults in this study who we identified as being Non-Religious Agonistic. In addition, agnostic emerging adults were the most likely to also express Extra-Theistic beliefs, with another ten of our interviewees expressing partially agnosticism in overlap with another cultural package.

Non-Religious-Atheist. The last of the belief-based groups is characterized by a firmer rejection of religion, theism, and spirituality of any kind. In describing their rejection of religious and spiritual beliefs, some of these emerging adults explained that they had logically reasoned themselves out of believing. For example, some attributed the problem of evil for their atheism. One interviewee explained: "If the world were all sunshine and roses, I might be more inclined to believe that there was somebody pulling the strings ... but I can't believe that there's someone pulling the strings making genocide." Another emerging adult expressed: "I still get told I'm going to hell, and so that has always made me, it led me to research other religions." Other young people identified with atheism simply as a reflexive rejection of theism. One young man explained, "I think I probably would consider myself to be atheist, but my atheism is not a central part of anything." Another young woman described that, "The only time I labeled myself like that [as an atheist] was when I was in the military, and that's simply because you had to." Only 18 of the 300 emerging adults in this sample were solely categorized as atheist, with an additional three partial atheists.

Combined, 79 of these emerging adults were solely Non-Religious, with an additional 19 who were partially Non-Religious. This equates to nearly one-third of the interviewees, for the second largest cultural package grouping, smaller than Theistic but larger than Extra-Theistic. Thus, one of the most evident findings of these results is confirmation of the initial overlap in categories identified by Ammerman (2013), with even further overlap found among a larger and national sample of emerging adults. Figure 1 visually represents these overlaps and shows that emerging adult religiosity and spirituality combine into non-binary categories. 




Figure 1. Complex and Overlapping Combinations of Religious and Spiritual Beliefs.

\subsubsection{Ethical Morality}

The second set of results describes our qualitative analyses of the morality questions. Ammerman (2013) describes ethical spirituality as a "common denominator," since the one thing all forms of religiosity and spirituality agree upon is "living a virtuous life" (p. 272). As with the belief-based cultural packages, we were curious about the source of ethical spirituality and viewed it as possibly cross-cutting the above sets of belief-based cultural packages. In investigating the source of ethicality, we find that responses grouped into two subcategories: Tacit-Morality and Cognitive-Morality. These descriptions refer to the extent to which interviewees described having conscious access to reasons for ethical decision-making or not.

Tacit Ethical Morality. When we asked emerging adults about their morality, and how they make decisions about right and wrong, many told us, "a gut feeling." For example, one emerging adult said, "your gut. I mean if you feel it's wrong, then it's probably wrong." Another said, "I know. It's just a, I don't know, a gut feeling, you know what's right and what's wrong." This interviewee went on to say: "I guess the hard part is deciding what to do about it, how to act on it, but um I don't really have, I never find myself thinking too hard about what's right and what's wrong." Many of these responses were not described as having a religious basis, totaling to 117 interviewees. An additional 98 of these responses came from emerging adults who described their gut feeling as stemming from religious beliefs. Similar to the first grouping, these emerging adults described morality as clear, straightforward, and relatively easy to apply to the right and wrong decision to make. Unlike the previous group, they described the reason for this being that morality was ingrained in them from their religious upbringing. For example, one interviewee said, "It's a lot a part of like who I am and like, and what I've learned from like church and the Bible and from God." She continues by saying she does not typically have to give it much thought because, "It usually is evident just because of who I am." Another emerging adult describes their tacit sense of morality by saying, "It would have to do with my religious background, [how] I was brought up. And then once again the values and 
the morals that were, that I was taught." As one emerging adult aptly described a tacit morality by saying, "I just kind of know." But in the same sentence, this interviewee also listed the sources for this morality as: "the Bible, my mom." When asked whether it was easy or hard to know what was right or wrong in a situation, another emerging adult said, "[I] think it's usually pretty clear. I mean, there're occasionally tough situations. And life's full of surprises. But I think most of the time, the answer's pretty straightforward." Yet another said, "scripture is very clear," and another said they implicitly know because, "it's just already inside of me from studying the Bible and being so involved in the Christian lifestyle." Combined, these 98 religiously infused tacit morality add to the 117 not specifically religious tacit morality interviewees to a tally of 215 of 300 emerging adults, more than two-thirds of the sample.

Cognitive Ethical Morality. In contradistinction to the emerging adults who described their sense of morality as tacit, ingrained, easy, and straightforward, another group talked instead about engaging in active cognitive effort to decide their sense of right and wrong. We call this cognitive morality, and view it as evidenced by statements such as: "I think it's much more important to be critically, to critically think about your own life and your own decisions." This emerging adult called it "dangerous" to "blindly accept" morality as prescribed by any social institution and instead thought morality deserved conscious attention. Another emerging adult described, "If something affects me, emotionally, immediately, I try to fall back, take a step back from the situation, and think about it. 'Cuz, you know, we [are] all human, we [are] emotional creatures. And sometimes we do irrational things because of our emotions." As opposed to the group who said morality was implicit and easy, another emerging adult in this group said the process of deciding right and wrong in this way: "I weigh out how it affects others, how it affects me, and then kinda go from there." Similarly, another said, "I try to think about how it's going to affect anyone who's involved, and if nobody's negatively affected then it's probably not bad." Yet another said, "It's tough, because everything's a grey ... It's very hard." The emerging adults in this cognitive morality group who did not explicitly mention engaging religious or spiritual content in their moral decision-making tallied to 66 interviewees. As with tacit morality, this cognitive morality group also had a second subcategory that described a similar process but also described religious or spiritual content. This was the smallest grouping of the ethical morality coding, with only seven interviewees explicitly in the religiously infused cognitive morality category. These emerging adults were typified by statements such as, "In Judaism there's more of a religion of laws than people realize ... It's not about what you feel; it's about what you do. Which I know is more of a lawyer way to look at the world, but that's why there are so many Jewish lawyers I think (laughs)." While this cognitive morality emerging adult describes thinking through right and wrong based on scriptures, another discusses relying upon praying and asking others: "Usually I would, like, pray about it ... I will ask someone's opinion. The people's opinion, who I think are more experienced in life than me." Another emerging adult in this category describes wrestling with personal desires versus religious teachings: "A lot of it comes down between personal feelings and religion. So, later on like, if I'm not in tune with my religious or spiritual self and I'll do it [make a wrong decision], and I don't help them [a person in need], and I get home and I feel bad, [then I know] that was the wrong choice. I shoulda done it." Another interviewee summarizes this group by saying their thought process is to ask: "What would be the moral high ground to take in a situation like this?" Then says, "and that's usually what I do." There were only seven in this religiously infused cognitive morality group; the other 66 cognitive morality emerging adults did not mention religion. Combined, these tally to 73 interviewees, less than one-quarter of the sample.

In addition, there were many interviewees that we categorized as a mixture of these tacit morality and cognitive morality categories. One interviewee at times described a non-religious tacit sense of morality, while at others drew upon a religious tacit sense. Another at times sounded similar to the non-religious tacit morality group, while at other times in the interview sounding the same as a religiously infused cognitive morality interviewee. An additional three expressed a combination of non-religious tacit and religious tacit, and eight interviewees described their morality in ways that 
combined non-religious tacit with non-religious cognitive morality. In summary, emerging adults described their ethical morality in ways that we categorized into two broad categories: implicit and cognitive. Each of these had subcategories of religious and non-religious, and there was a small group of emerging adults who evidenced hybridization across all four of these categories. Ethical morality codes were crosscutting with the three belief-based cultural packages, as the content of the religious or non-religious beliefs described was consistent with the theistic, extra, and non-religious categories.

Thus, we find that more than two-thirds of these emerging adults expressed a tacit ethical decision-making process, with their sense of morality internalized beyond cognitive access and without need of conscious attention. Slightly more than half of these described the source of their sense of morality in non-religious terms, while nearly a half described a religious source.

\subsection{Experimental Results}

In response to this national-level finding on the general dearth of reflexivity regarding the moral basis for ethical decision-making, we conducted a second study that investigates changes over time in response to an experimental intervention designed to increase moral awareness.

\subsubsection{Clarifying Moral Values}

At Time 1 of the experimental study, two-thirds (75 percent) of the emerging adults in both the primary and control groups said they had positive feelings toward and understood their faith, and nearly three-quarters (71 percent) reported that they clearly understood their moral values. However, less than one-tenth (7 percent) said they could easily identify their moral values. At Time 1, 70 percent of the participants said that when faced when difficult life decisions they would decide what to do based on their framework of beliefs and values (as compared to the other response options of what feels right at the time, views of friends, views of parents, and what is most beneficial in the short to medium term). In measuring changes over time, the rate declined by four percent at Time 2 for the comparison groups of similar emerging adults receiving the ethics-only content. In comparison, the rate for emerging adults in the treatment group increased by five percent at Time 2 .

Moreover, at Time 2 all the emerging adults in the treatment group reported clearly understanding their beliefs and values. This reflected an increase in agreement with this statement by one-quarter of the group, as compared to no statistically significant change in agreement among control groups. Lastly, net of Time 1 responses, and in comparison to control groups, the treatment group participants had a statistically significant Time 2 decrease in their agreement with personal gain weighing more heavily than principles in their decision-making. This provides some initial evidence that the experimental intervention aids some in making ethical decisions that are based on a clearer sense of values and not solely on personal gain.

\subsubsection{Articulated Value Statements}

In analyzing the personal mission statements with the cultural package framework described in the first study, half of participants in the experimental intervention explicitly referenced having a Doctrine-Theistic belief system in their value statement. Examples of these values statements are one female emerging adult stating: "My most important value is my faith. It is my way of life and the most critical thing that influences my decisions. My faith in God keeps me centered, calm, and focused. It helps give my life meaning and a distinct purpose. I know God will always be by my side and help me along my journey." A male emerging adult described, "My mission is to be a man who has an open home and to have an open heart that any who would desire to seek refuge in either would be able to do so readily for the mission that is missions for the Gospel of Christ."

Another emerging adult described how she saw her moral values impacting her life pursuits by saying, "In this life I want to accomplish great things-at work, school and even in my personal life. Whatever I work at and accomplish I want to point everything back to Jesus because through him I am able to do all things." In reflecting on future workplace goals, another emerging adult described 
his values in this way: "My life mission is to be a Christian man in the business world, showing that I am dedicated to my job, my faith and my family ... I plan to have my faith in God be the center of my life and be the motivation for all that I do." In succinctly summarizing how participants with a Doctrine-Theistic belief system articulated the connection to their ethical decision-making, this emerging adult explained her values by saying, "Integrity, to me, means letting my Christian morals guide me in all aspects of life." One emerging adult articulated an Extra-Theistic belief system that viewed himself as a vehicle for transcendence by saying, "My enthusiasm will light a fire under people to accomplish their own goals as it transfers through my attitude, facial expressions and tone of voice." He continued: I will show people that by creating their own reality they can innovate in every part of their lives and be more in control of their outcomes than they once were before."

The remaining nearly one-half of participants did not explicate any religious belief system in their value statement. Examples of value statements from these participants are this from a male emerging adult: "My mission is to always live life to the fullest, bring honor to my family, and continue to defy the odds." A female emerging adult stated, "I will do this by not blaming my unhappiness on others, pushing my self to strive for new challenges and be honest about my mistakes." Another female emerging adult said, "I will always stay true to myself and my values, I will continue to learn every day, and I will focus my energy on helping others and maintaining lifelong relationships." The lack of explication of a belief system did not allow for a more thorough parsing as to whether these participants are Non-Religious in their beliefs, or could have been coded as Heritage-Theistic or Extra-Theistic with access to further information. Nonetheless, it was evident that they did not articulate Doctrine-Theistic beliefs in their value statements, meaning about one-third of the participants who reported clear understandings of their faith and moral values at the beginning of the semester did not by the end of the treatment cognitively link their values to their religious beliefs, while the other two-thirds connected these.

\subsubsection{Impact of Value Reflections}

In participant essays, emerging adults articulated a number of change mechanisms from the intervention approaches. We coded these into one of five inductively developed themes, listed in order of their prevalence: gaining greater reflexivity, heightened cultural awareness, becoming more concerned about the welfare of others, developing a greater sense of purpose in life, and learning skills to relax and de-stress, the latter of which were primarily gained through meditation techniques taught during the intervention. For this paper, we report the most prevalent results: gaining greater reflexivity. Participant essays in this category made statements such as, "Through this class, my values have been solidified ... [This class] is an opportunity to look into yourself and find that what you believe in and what you value, the basis of who you are." Another emerging adult expressed, "My understanding of my goals, values and mission has undergone a dramatic facelift this semester." A third said, "[This class] has helped me articulate my values and beliefs while helping me define them when they were unclear." A fourth emerging adult stated: "I do feel more like I've organized my beliefs into a coherent thing instead of the mildly blurry romantic mess they were before." Thus, it appears from these reports that the intervention was helpful in facilitating participants in gaining greater clarity of their moral values through a process of reflexivity.

In discussing what if any impact this would have on everyday life, one emerging adult said, "I knew some of my goals and values, but I hadn't really thought much about how I would actually reach it ... After having gone through these exercises, I firmly believe I can not only state my goals that I have had but how I will go through my daily life to attain them." Another said, "This class has given me a new perspective and meaning to my life... By narrowing down my core values to my top five, I am now able to use them daily to make decisions." Yet another described learning over the semester: "The first draft of my personal mission statement was more focused on what I wanted to feel than what I intended to do, and was very vague and 'fluffy.' As I progressed in the course, I began to look further inward and reframe what 1 wanted into what I could do in order to improve my life." 
Thus, it appears from these descriptions that this intervention aided participants in making their moral values more explicit by engaging in a cognitive process of reflexivity. While many of the participants were Doctrine-Theistic, they still had at the outset of the intervention the same general pattern found in the national study of mostly relying upon a tacit sense of their moral values. However, it appears this intervention aided participants in gaining greater access to the taken-for-granted beliefs embedded in their ethical decision-making and a sense of how to clearly articulate this to others. Participant descriptions indicate this change will continue to impact their ethical decision-making.

\section{Discussion}

In summary, we find support in the both the national study analysis and the experimental study for non-binary combinations of religiosity and spirituality. In fact, we find even greater overlap among the categories than originally identified when examining the relationships between religiosity and spirituality among this sample of emerging adults. This contributes a more complete taxonomy of religious and spiritual cultural packages, and in a generalizable sample of American emerging adults. A second contribution is to separate the cultural package that Ammerman (2013) referred to as Ethical Spirituality into a different category that focuses on articulation of the moral values undergirding ethical decision-making. We evidence that this category crosscuts the belief systems of the ten cultural packages and differentiate Tacit versus Cognitive Ethical Morality, both of which have religious and non-religious articulations.

In the expeirmental study, we investigated an intervention designed to elevate awareness of moral values, and the religious and spiritual belief systems underlying these values. In so doing, we found initial evidence that the intervention aids participants in making their moral values less tacit, providing an opportunity to cognitively process the beliefs undergirding their actions. This further articulation of value statements appears to have led to a small increase within a relatively short duration in participant ratings that they will rely upon their framework of beliefs and values when making difficult life decisions, as compared to a reported decrease among control participants. Participants reported that this reflexive process aided them in gaining greater clarity regarding their values and also in linking their moral values to their ethical decision-making.

\subsection{Theoretical Framework}

Based on the combination of results from these two studies, we propose a theoretical framework that is represented in Figure 2. Drawing especially on the change mechanisms described by emerging adults participating in the intervention group, we theorize that beliefs about religion and spirituality (A), including secular beliefs, undergird moral values (B), which are expressed through ethical decision-making (C). We find in the national study that most emerging adults are not cognitively aware of the underlying beliefs and values behind their ethical decision-making processes. Yet we find through the intervention in the experimental results that emerging adults can be facilitated in gaining a greater awareness of their undergirding beliefs and values.

This theoretical framework aids an understanding of the social changes surrounding young Americans, and associated changes in their socialization for adulthood transitions. Young Americans are growing up and preparing to work in diverse religious and spiritual milieus, which can support a plethora of belief systems. Traditional workplace education has focused on preparing students to make ethical decisions (Ghoshal 2005; Vitell 2009). However, globalizing workplaces combined with decades of findings on slowly declining rates of U.S. religious participation (Smith 2005; Chaves 2011) alter workplace contexts, and changing life course socialization (Arnett 2015) alter the processes by which emerging adults formulate, become cognitively aware of, and express their belief-value-action orientations. A risk of this diverse cultural milieu is that emerging adults lack clarity regarding the values undergirding their ethical decision-making, leaving personal gain as perhaps the only clear motivating factor. Our study implies that an alternative to moral and cultural relativism is to provide emerging adults with interventions designed to facilitate their moral awareness. Rather than the 
approach of religiously based moral education programs designed to facilitate expression of a singular belief system, we find merit in an intervention designed to facilitate ethical decision-making with the primary change mechanism as exposure to diverse religious and spiritual beliefs, including secular beliefs, coupled with reflexivity on personal moral values.

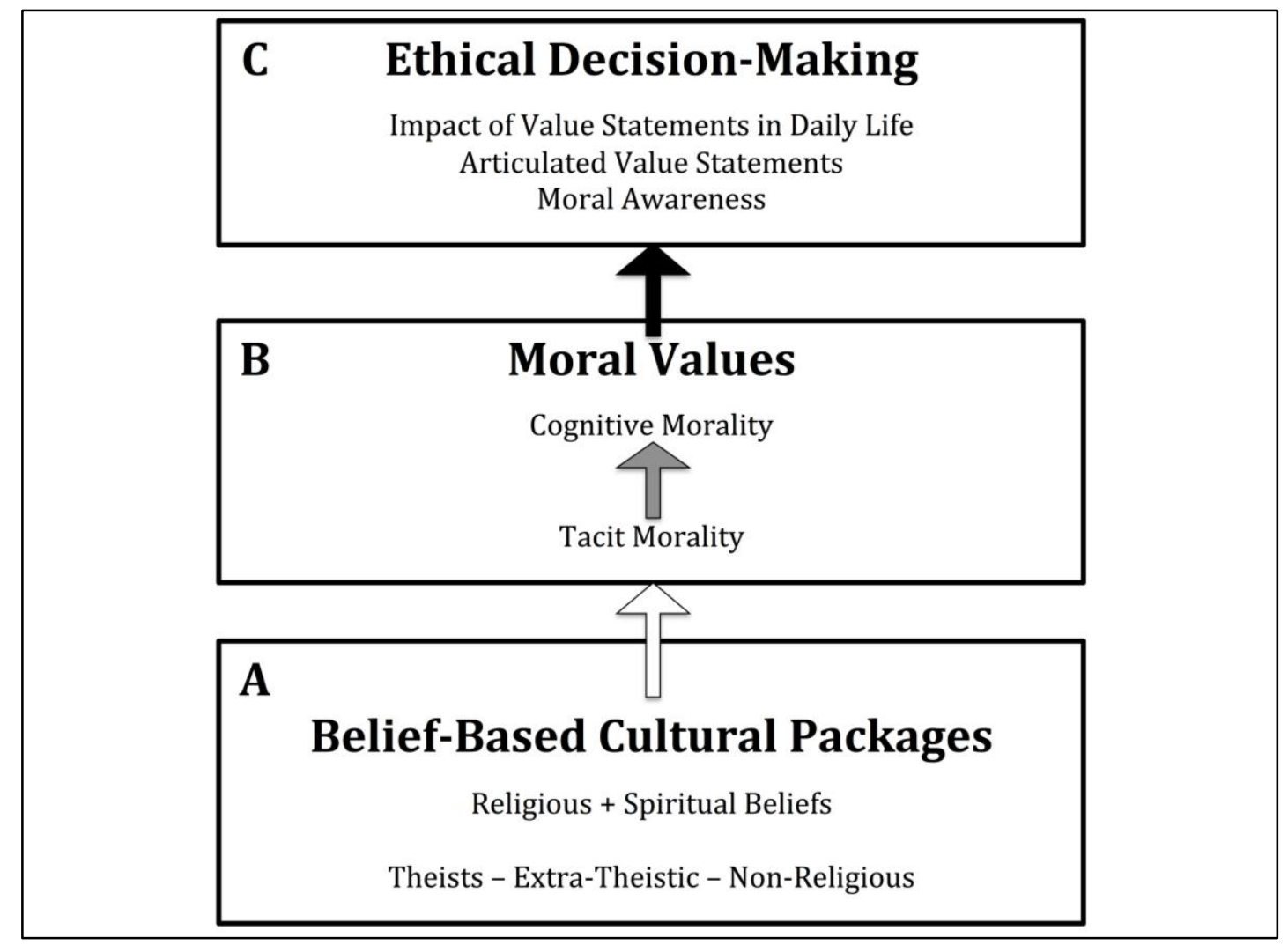

Figure 2. Theorized Link Between Beliefs, Moral Values, and Ethical Decision-Making.

\subsection{Limitations and Future Studies}

Despite drawing upon the strengths of a mixed-methods design, this study has a few limitations. The sample for the experiment is a small, non-representative sample in the southern U.S. and thus needs to be interpreted within the confines of that sample, while providing evidence that a larger-scale study is warranted. Another limitation of the experiment is the short duration of the longitudinal component. A fruitful avenue for future studies is to track emerging adults for longer durations to investigate how clarification of moral values relates to later life and workplace experiences. A third limitation of the study is its reliance upon self-reported data. Future studies could advance the results found here by studying workplace outcomes-including evaluations of ethical decision-making by others, as well as observational data. These data could be linked with the self-reported data collected in this study for associations between reported changes and behavioral expressions of ethical decision-making in social settings, such as workplaces.

Acknowledgments: The authors are indebted to Grant King, Tiffany Hood, and Sanjana Vanguopal for their research assistance, to Daniel Harris for lending his class as the experimental treatment, and to the Tyson Center for Faith and Spirituality in the Workplace for contributing to the research design.

Author Contributions: Patricia Snell Herzog designed the study, supervised analysis, and wrote the paper. De Andre' T. Beadle assisted with qualitative coding and paper editing.

Conflicts of Interest: The authors declare no conflict of interest 


\section{References}

Arnett, Jeffrey Jensen. 2015. Emerging Adulthood: The Winding Road from the Late Teens through the Twenties, 2nd ed. New York: Oxford University Press.

Ammerman, Nancy T. 2013. Spiritual but Not Religious? Beyond Binary Choices in the Study of Religion. Journal for the Scientific Study of Religion 52: 258-78. [CrossRef]

Ammerman, Nancy T. 1997. Golden Rule Christianity: Lived Religion in the American Mainstream. In Lived Religion in America: Toward a History of Practice. Edited by David Hall. Princeton: Princeton University Press, pp. 196-216.

Baker, Joseph O. 2012. Perceptions of Science and American Secularism. Sociological Perspectives 55: 167-88. [CrossRef]

Berghuihs, Joantine, Cok Bakker, and Jos Pieper. 2013. New Spirituality and Social Engagement. Journal for the Scientific Study of Religion 52: 775-92. [CrossRef]

Chaves, Mark. 2011. American Religion: Contemporary Trends. Princeton: Princeton University Press.

Cimino, Richard, and Christopher Smith. 2007. Secular Humanism and Atheism beyond Progressive Secularism. Sociology of Religion 68: 407-24. [CrossRef]

Comer, Debra R., and Gina Vega. 2011. Moral Courage in Organizations: Doing the Right Thing at Work. Armonk: Routledge.

Crosby, Donald A. 2003. Transcendence and Immanence in a Religion of Nature. American Journal of Theology $\mathcal{E}$ Philosophy 24: 245-59.

Davie, Grace. 1994. Religion in Britain since 1945: Believing Without Belonging. Cambridge: Wiley-Blackwell.

Durkheim, Emile. 2008. The Elementary Forms of Religious Life. Edited by Mark S. Cladis. Translated by Carol Cosman. Oxford: Oxford University Press. First published 1915.

Erikson, Erik H. 1950. Childhood and Society. New York: W W Norton \& Co.

Farias, Miguel, and Mansur Lalljee. 2008. Holistic Individualism in the Age of Aquarius: Measuring Individualism/Collectivism in New Age, Catholic, and Atheist/Agnostic groups. Journal for the Scientific Study of Religion 47: 277-89. [CrossRef]

Gentile, Mary C. 2010. Giving Voice to Values: How to Speak Your Mind When You Know What's Right. New Haven: Yale University Press.

Ghoshal, Sumantra. 2005. Bad Management Theories Are Destroying Good Management Practices. Academy of Management Learning E Education 4: 75-91.

Giacalone, Robert A. 2007. Taking a Red Pill to Disempower Unethical Students: Creating Ethical Sentinels in Business Schools. Academy of Mgmt. Learning E Education 6: 534-42.

Guerra, Valeschka M., and Roger Giner-Sorolla. 2010. The Community, Autonomy, and Divinity Scale (CADS): A New Tool for the Cross-Cultural Study of Morality. Journal of Cross-Cultural Psychology 41: 35-50. [CrossRef]

Jensen, Lene A. 2008. Through Two Lenses: A Cultural-Developmental Approach to Moral Psychology. Developmental Review 28: 289-315. [CrossRef]

Kenworthy, Amy L. 2013. Introduction: Entrepreneurship, Economics, Ethics, Morality, and War-Tools for Addressing Difficult Interdisciplinary Topics in Our Interdisciplinary World. Academy of Management Learning E Education 12: 142-44.

Kohlberg, Lawrence. 1964. The Development of Moral Character and Ideology. In Review of Child Development Research. Edited by Martin L. Hoffman. New York: Russell Sage Foundation.

LeDrew, Stephen. 2013. Discovering Atheism: Heterogeneity in Trajectories to Atheist Identity and Activism. Sociology of Religion 74: 431-53. [CrossRef]

Marti, Gerardo. 2009. Affinity, identity, and transcendence: The experience of religious racial integration in diverse congregations. Journal for the Scientific Study of Religion 48: 53-68. [CrossRef]

Padilla-Walker, Laura M. 2016. Moral Development during Emerging Adulthood. In The Oxford Handbook of Emerging Adulthood. Edited by Jeffrey J. Arnett. New York: Oxford University Press.

Putnam, Robert D., David E. Campbell, and Shaylyn Romney Garrett. 2012. American Grace: How Religion Divides and Unites Us. New York: Simon and Schuster.

Oppenheimer, Mark. 2014. Examining the Growth of the 'Spiritual by Not Religious'. New York Times, July 18. Available online: http:/ / www.nytimes.com/2014/07/19/us/examining-the-growth-of-the-spiritual-butnot-religious.html (accessed on 15 January 2018). 
Roof, Wade Clark, and William McKinney. 1992. American Mainline Religion: Its Changing Shape and Future. New Brunswick: Rutgers University Press.

SBNR. n.d. Available online: www.sbnr.org (accessed on 15 January 2018).

Smith, Christian, and Melissa Denton. 2005. Soul Searching: The Religious and Spiritual Lives of American Teenagers. New York: Oxford University Press.

Smith, Christian, and Patricia Snell. 2009. Souls in Transition: The Religious and Spiritual Lives of Emerging Adults. New York: Oxford University Press.

Smith, Jesse M. 2013. Creating a Godless Community: The collective Identity Work of Contemporary American Atheists. Journal for the Scientific Study of Religion 52: 80-99. [CrossRef]

Smith, Tom. 2005. Generation Gaps in Attitudes and Values from the 1970s to the 1990s. In On the Frontier of Adulthood: Theory, Research, and Public Policy. Edited by Richard A. Settersten Jr., Frank F. Furstenberg and Rubén G. Rumbaut. Chicago: University of Chicago Press.

Vitell, Scott J. 2009. The Role of Religiosity in Business and Consumer Ethics: A Review of the Literature. Journal of Business Ethics 90: 155-67. [CrossRef]

Wuthnow, Robert. 2007. After the Baby Boomers: How Twenty-and Thirty-Somethings are Shaping the Future of American Religion. Princeton: Princeton University Press.

Zinnbauer, Brian J., Kenneth I. Argument, and Allie B. Scott. 1999. The Emerging Meanings of Religiousness and Spirituality. Journal of Personality 67: 889-919. [CrossRef]

(C) 2018 by the authors. Licensee MDPI, Basel, Switzerland. This article is an open access article distributed under the terms and conditions of the Creative Commons Attribution (CC BY) license (http://creativecommons.org/licenses/by/4.0/). 